\title{
Does Trade Flow between Turkey and Germany Justifies Ricardian Theory?
}

\author{
S. Güneş, F. Yeşilyurt, and H. S. Karaalp
}

\begin{abstract}
Classical Ricardian theory of comparative advantage states that differences in labor productivities determine trade patterns. Many publications have focused on labor productivity differences as an important variable in determination of trade flows among countries. However few studies focused on both productivity and labor cost differences and their effects on countries' export performance. Unit labor cost (ULC) combines the effects of productivity, labor cost and exchange rate. An increase in ULC implies that labor costs rise more than productivity gains. As a result, comparative advantage deteriorates. The aim of this study is to contribute validity of classical model by inquiring the effect of relative unit labor cost (RULC) in determination of trade flows between Turkey and Germany. We used annual Turkish and German data for the period of 2002 to 2008 for five major manufacturing sectors which are food and beverages, tobacco products, textiles, wearing apparel, leather and leather products. Export and import data are obtained from TurkStat. The ULC data set are calculated by using UNIDO value added and wage data set. The estimation results show that Ricardian theory explains trade pattern between Turkey and Germany. Increase in relative unit cost in Turkey effects relative export performance of Turkey negatively.
\end{abstract}

Index Terms-Productivity, trade flows, time series, unit labor cost.

\section{INTRODUCTION}

Mercantilism was the dominant economic policy over the period from the 16th century to the late 18th century. However, in 1776, Adam Smith published "The Wealth of Nations" which can be used as the formal beginning of Classical Economics and mentioned the importance of specialization through international division of labor. International free trade theory begins with absolute advantageous theory of Adam Smith and followed by Ricardo's comparative advantage theory. Both of which mainly focus on labor productivity differences among countries in determination of trade flows. Then Heckscher-Ohlin theory mentioned the importance of differences in both factor abundance of trading partners and factor intensities of commodities in determination of trade flows. In addition to inter industry trade theories, new international trade theories also analyze the determinants of intra-industry trade flows between nations. According to Linder hypothesis, trade takes place among similar countries to provide variety for consumption. Reference [1] mentions the importance of quality differences, externalities of clusters, research on innovation and domestic competition and

Manuscript received October 14, 2012; revised December 18, 2012.

S. Güneş is with Pamukkale University, Denizli, Turkey (e-mail:sgunes@pau.edu.tr). strategic behavior of firms in determination of countries' competitiveness level. Reference [2] states that cost advantages of increasing returns to scale industries and importance of geography are important variables in determination of trade flows between countries. New trade models like gravity model states that trade is proportional to two countries' gross domestic product (GDP) and negatively proportional to their distance. Although there are various international trade models, classical model is one of the most important models in explanation of trade patterns. Classical theory of Ricardo states that comparative advantage which based on relative labor productivity differentials determines both international specialization and trade pattern between two countries. Each country produces and exports of those goods in which the relative output per worker was more than the relative money wages of workers. In this context comparative cost advantage plays an important role in determination of a country's trade flows. Cost of tradable inputs have tendency to be equalized internationally. Due to capital and raw materials are much more tradable than labor, testing classical trade theory by assuming labor theory of value still make sense.

Price of commodity is one of the most important variables in determination of comparative advantage. Both labor productivity and labor cost have considerable influence on determination of goods' prices. So, comparing countries relative unit costs may give information about their competitiveness level [3]. A country may have a comparative advantage over commodity exports if the ratio of domestic productivity to productivity abroad exceeds the domestic wage ratio to wage ratio abroad. Labor cost per unit of output (unit labor cost (ULC)) is the ratio of wages to its productivity. Provided that labor wage level remains unchanged, if labor productivity decreases, ULC rises or vice versa [4]. In other words the inverse of productivity that is unit labor requirement ratio is used in calculation of ULC. So both changes in wage level and worker productivity affect ULC. Reference [5] concluded that relative unit labor cost (RULC) is probably the best indicator in measuring industrial countries' competitiveness level for manufacturing sector. In this context, cost competitiveness of sector $i$ in country $j$ compared with country $k$ depends on RULC and it could be calculated using following formula:

$$
\mathrm{RULC}_{i j k}={ }_{i j} w_{i j} / a_{i k} w_{i k} e_{j k}
$$

$a_{i j}, a_{j k}$ Unit labor requirements for countries $j$ and $k$ respectively. It is calculated through getting the ratio of labor employment to value added

$w_{i j}, w_{i k}=$ Wage levels for countries $j$ and $k$ respectively 


\section{$e_{i k}=$ Bilateral exchange rate}

As both Turkey's and Germany's export pattern relies on manufacturing industry, the RULC variable is employed. So, we expect that trade flows and ULC relationship between Turkey and Germany can be more explicitly explored.

Turkey signed Custom Union Treaty with European Union in 1996. Existing tariff barriers or other protectionist non-tariff implementations are at the minimum level between Europe and Turkey. Germany is also the most important trade partner for Turkey for the sample period. For instance, in 2008 and 2011, exports from Turkey to Germany was 13.9 million \$ and 9.8 million \$, respectively. In the years of 2008 and $2011,9.8 \%$ and $9.5 \%$ of Turkey's exports were realized to Germany. Turkey's imports from Germany was 18.6 million \$ and 22.9 million \$ in 2008 and 2011, respectively [6]. In this context, we analyzed the effect of RULC for Turkey's export competitiveness relative to Germany over the period between 2002 and 2008. The main contribution of this study to the literature is that it examines the effect of RULC on Turkey's export competitiveness relative to Germany.

This paper proceeds as follows: Following introduction, section II summarizes recent empirical studies. Section III describes the variables and discusses the empirical findings of the model. Section IV provides concluding remarks.

\section{LITERATURE}

Comparative cost advantage plays an important role in determining a country's trade flows. Since labor theory of value is assumed, both labor productivity and cost differential are important variables in determination of export share. The simplicity of Ricardian model reveals its strength so; older tests of the model were highly successful. First empirical study was conducted by [7]. He tested classical theory by comparing output per worker and wage level. The dependent and independent variables were ratio of US to UK exports and relative labor productivity, respectively. In other words, it is expected that each country will export goods for which the ratio of its productivity exceeds the ratio of money wage rate to that of the other. For the sample period American wages were twice of the British wages. This study, covering $97 \%$ of the sample, showed that American manufacturing sectors which have per worker productivity more than two dominated bulk of the market and American manufacturing sectors having output per worker less than two had lost bulk of the market power. This study had found clear positive relationship between labor productivity and exports. And this study had also found a strong inverse relationship between US and UK relative wage costs per unit of output and relative exports.

Similar to the previous study, [8] used total export ratio but also included RULC as an independent variable besides relative productivity. Results of this study indicated that comparative costs provide an important explanation of relative export performance between UK and US. This study found that differences in the ULC ratio tended to be associated with a somewhat larger inverse percentage difference in relative export quantity. By relaxing the strict labor theory of value assumption, costs other than labor were also included into analysis. There is a negative relationship between output per worker and net costs which are representing per unit cost of production in the value added sense. But [8] added that net cost variable is not as good predictor as relative output per worker or ULC.

The independent variable in [9] was export to third markets rather than bilateral trade volume between UK and US. This study employed relative labor productivity as the main explanatory variable. Results show that correlation coefficient between productivity ratios and export shares higher than net unit cost ratio and export shares. This study found inconclusive evidence that higher wages might be associated with higher export shares. This situation tried to be explained by unidirectional relationship, in which higher export shares might result higher wages. Another study also supported that labor productivity variable correlates with export performance of Canada and the US [10].

ULC for motor vehicle and steel industries for the US, Japan and Industrialized Europe is examined by [11]. Results supported that ULC is a good indicator to measure trade position in these two industries. Another study, examined the structure of trade flows in manufacturing industries over the period between 1967 and 1982 [12]. In this study, to estimate individual industry effects, fixed panel estimation method is used. The results of labor productivity variable are consistent with the classical theory. A positive relationship between labor productivity and export performance was found. But labor compensation variable gave contradictory results. There was both high level of labor productivity and relatively high level of labor costs.

Purchasing power parity theory assumes law of one price for tradable manufactured goods. This theory can be extended for tradable input prices. Reference [13], mentioned that as other tradable input prices equalized internationally, labor is the most important factor in determination of cost competitiveness. In this context input prices also converge to each other. This study was extended by [3]. They tested the relationship between trade flow, relative labor productivity and ULC by using larger group of countries vis-a-vis the US for 21 manufacturing sectors. The countries which are used in empirical analysis are; Japan, Germany, France, UK, Italy, Canada, Australia, Korea and Mexico. In this analysis labor compensation data is used to generate ULC. Empirical results seem to support Ricardian theory of comparative advantage. Although explanatory power of regressions are weak, majority of coefficients are correctly signed and most are statistically significant.

RULC is one of the most important variables in determination of trade flows for manufactured goods among industrial countries [5]. Reference [14] found that even if his estimates had low explanatory power, comparative advantage depends on both factor abundance and differences in labor productivity.

By using quarterly data a time series analysis applied for Turkey by [15]. They stated that ULC has substantial effect in the determination of international competitiveness of Turkey. The 2001 crises caused relatively higher productivity and relatively lower dollar based wages and resulted in comparatively lower ULC in Turkey. Their empirical results showed that export performance of Turkey had increased for 
the period from 1999 to 2003.

A comparison of relative levels of ULC for several OECD countries relative to the US was tested by [16]. Their study decomposed ULC effects into productivity, labor cost and relative price performance. Main result of this study is that lower productivity levels tend to correlate with relative lower labor cost levels. Low productivity level rather than high labor cost threatens countries' competitiveness level.

Reference [17], compared Senegalese manufacturing industry international competitiveness level with Africa, Asia, South America and Eastern/Central Europe. This study concluded that besides world demand, the exchange rate, and relative wages in dollar terms and relative level of productivity are important variables in determination of Senegalese's export competitiveness.

The relationship between productivity growth and export volume of Taiwan electronics industry was examined by [18]. This study found that compared to other sectors, exporters in the electronics industry have higher productivity. Another study also tested the existence of Ricardian theorem between South Africa and the US on 23 manufacturing industries [19]. They also concluded that the trade pattern supports the Ricardian theorem. The equation of Balassa [9] was estimated in the study of [20]. Although there is a change in value of coefficients, this study also supported previous findings of Balassa [9] that is labor productivity difference is the main explanatory variable in determination of export performance.

\section{Model AND DATA}

Ricardian theorem is used to explain bilateral trade pattern between Turkey and Germany by using panel data approach on five manufacturing industries which are food and beverages, tobacco products, textiles, wearing apparel, leather and leather products. Bilateral trade flow data between Turkey and Germany is used to escape aggregation bias problem. The data set is annual data and ranges from 2002 to 2008. Trade data are obtained from TurkStat (Turkish Statistical Institute) according to 2 -digit levels of ISIC (Revision 3) [21]. As it is stated in previous studies, the ULC variable could be used to analyze export performance. Changes in ULC gives information about both labor and market efficiencies. So, ULC data is used as an explanatory variable to represent a link between productivity and cost of labor in the production of the output. The ULC variable is calculated by using wage level and value added data set. These data are provided from UNIDO [22]. Relative export performance of Turkey with Germany is the dependent variable of the model. All variables are transformed to natural logarithms. In this context, to examine the validity of the Ricardian model and measure the strength of the relationship between RULC and export performance. A simple panel equation can be written as the following form:

$$
\log \left(\mathrm{EXP}_{i, t} / \mathrm{IMP}_{i, t}\right)=\beta_{1}+\beta_{2} \log \mathrm{RULC}_{i, t}+\varepsilon_{i, t}
$$

where, EXP/IMP is Turkey's Exports to Germany divided by Turkey's Imports from Germany. $R U L C$ is Turkey's ULC divided by Germany's ULC.

There are some advantages of panel data analysis such as increasing the degrees of freedom and improving the efficiency of the estimations by reducing collinearity among explanatory variables [23]. Panel data estimation method also offers researchers the possibility to control for individual heterogeneity [24]-[25]. In this context, we used panel data estimation technique and employed some tests to decide appropriate model.

First, we employed redundant fixed effect test and we found that the hypothesis of "pooled ordinary least square (OLS)" versus "fixed effects" in time and in cross section couldn't be rejected. In other words, the null hypothesis of "pooled OLS" is accepted. As a first result, "pooled OLS" is preferred to fixed effects model. Second we examined the null hypothesis of "pooled OLS" against "random effects" in both cross section and period by using Breusch-Pagan LM Test. According to the test result we rejected the null hypothesis pooled OLS and we conclude that "random effects" model is appropriate for our model at 1\% significance level. As a third step, we applied Hausman Test to identify whether "the random effects" or "the fixed effects" are appropriate for our model. According to the test result we accepted the null hypothesis and we concluded that the preferred model is random effects model. As a result of all these empirical tests, we decided to use random effects model in this study. However, to make comparison of all models we estimate (2) by using pooled OLS, fixed effects and random effects and we lay out the results in Table I. In this context, estimation results revealed that pooled model, fixed effect model and random effect model produce the same results. The same results of pooled OLS and random effects also show the efficiency of random effects estimator.

TABLE I: ESTIMATION RESULTS

\begin{tabular}{llll}
\hline \hline & Pooled OLS & Fixed & Random \\
\hline Variable & & & \\
constant & -0.19 & -0.45 & -0.19 \\
RULC & $-0.35^{*}$ & $-0.46^{*}$ & $-0.35^{*}$ \\
$R^{2}$ & 0.21 & 0.29 & 0.21 \\
Cross Section F & 0.85 & & \\
Period F & 0.19 & Breusch Pagan LM & $66.44^{*}$ \\
& & Test & \\
Cross Section/ & 0.42 & Hausman Statistic & 1.95 \\
Period F & & & \\
\hline \hline Note: $*$ indicates that the corresponding coefficient is significant at $1 \%$ level
\end{tabular}

The results in Table I showed that the RULC variable is statistically significant and has the expected sign. Increase in ULC cause a decrease in Turkey's export performance as expected. Furthermore empirical results showed that there is a negative relationship between relative export performance of Turkey and RULC. We may conclude that if Turkey's ULC increase more than Germany's ULC, export performance of Turkey deteriorates. 


\section{CONCLUSION}

Economic theory consists of a number of economic models. Each model tries to explain theories with explanatory variables and make predictions for the future. New international trade theories had focused on both inter and intra industry trade flows between nations. These theories have also being tested with tremendous amount of empirical studies. Despite many complex new international trade theories, this analysis focuses on mainly simple classical theory of Ricardian Comparative Advantage and tested existence of Ricardian theory between Turkey and Germany which is the most important trade partner of Turkey. As far as we know, there isn't any empirical study to test the relative cost and export performance between Turkey and Germany. As mentioned before most of studies had analyzed determinants of US and UK trade flows. That is why this study contributes existing empirical literature.

By relying on existing empirical literature, the ULC variable is used to explain relative export performance differences of Turkey and Germany. Although cost of capital and raw materials can also be crucial factors for comparisons of export performance between countries, labor cost differential had been mentioned as a good indicator for measuring export performance [8]-[9].

As a result, this study empirically shows that Ricardian theory still has a word to say in explanation of trade flows between Turkey and Germany. When Turkey's ULC increase more than Germany's ULC, Turkey's relative export performance was affected negatively.

\section{REFERENCES}

[1] M. E. Porter, Rekabet Üzerine, Harvard Business School Publishing Corporation (çev. Kıvanç Tanrıyar), Optimist Yayın, no. 211, pp. 1 $-568,2008$.

[2] P. R Krugman and M. Obstfeld, International Economics, $8^{\text {th }}$ ed., Pearson Education Inc, pp. 1-705, 2009.

[3] S. S. Golub and C. T. Hsieh, "Classical Ricardian theory of comparative advantage revisited," Review of International Economics, vol. 8, no. 2, pp. 221-234, May 2000.

[4] T. Eicher, J. H. Mutti, and M. H. Turnovsky,International Economics, $7^{\text {th }}$ ed., Routledge, pp. 1-784, April 2009.

[5] P. Turner and J. Van't Dack, "Measuring International Price and Cost Competitiveness," Bank for International Settlements Economic Papers, no. 39, pp.1-152, November 1993.

[6] TurkStat. Foreign Trade Statistics. [Online]. Available: http://www.turkstat.gov.tr/VeriTabanlari.do?ust_id=4\&vt_id=7

[7] G. D. A MacDougall, "British and American exports: A study suggested by the theory of comparative costs," The Economic Journal, vol. 41, no. 244, pp. 697-724, September 1952.

[8] M. R. Stern, "British and American productivity and comparative costs in international trade," Oxford Economic Papers, vol. 14, no. 3, pp 275-296, October1962.

[9] B. Balassa, "An empirical demonstration of classical comparative cost theory," The Review of Economics and Statistics, vol. 45, no. 3, pp. 231-238, August 1963.

[10] J. D. Stryker, "The sources of change in export performance: The USA and Canada," P. Kenen and R. Lawrence Eds. The Open Economy Essays on International Trade and Finance. New York: Colombia University Press, 1968, pp. 150-174, 1968

[11] M. E. Kreinin, "Wage competitiveness in the US auto and steel industries," Contemporary Economic Policy, vol. 2, no. 4, pp. 39-50, January 1984.

[12] A. Solocha, "Comparative cost advantage and trade performance: A panel data Approach," The International Trade Journal, vol. 5, no. 3, pp. 403-416, June 1991.

[13] A. G. Turner and S. S. Golub, "Multilateral Unit Labor Cost Based Indicators of Competitiveness for Industrial, Developing and
Transition Economies," IMF Staff Studies for the World Economic Outlook, pp. 1-47, December 1997.

[14] J. Harrigan, "Technology, Factor Supplies, and International Specialization: Estimating the Neoclassical Model," American Economic Review, American Economic Association, vol. 87, no. 4, pp. 475-94, September 1997.

[15] N. Keyder, Y. Sağlam, and K. M. Öztürk, "International competitiveness and the unit labor cost based competitiveness index," METU Studies in Development, vol. 31, pp. 43-70, June 2004.

[16] B. V. Ark, E. Stuivenwold, and G. Ypma, "Unit Labor Costs, Productivity and International Competitiveness," Key Indicators of the Labour Market, Fourth Edition, pp. 1-9, August 2005

[17] A. A. Mbaye and S. Golub, "Senegalese manufacturing competitiveness: A sectoral analysis of relative costs and prices," African Integration Review, vol. 1, no. 1, pp. 96-128, January 2007.

[18] M. W. Tsou, J. T. Liu, and K. H Wang, "Exporting and productivity growth: Evidence from the Taiwan electronics plants, Scottish Journal of Political Economy, vol. 55, no. 2, pp. 190-209, May 2008.

[19] O. A. Akanbi and A. C. Jordaan, "The Ricardian theory of comparative advantage between South Africa and the USA in the manufacturing sector," Studies in Economics and Econometrics, vol. 32, no. 2, pp. 25-44, 2008.

[20] G. Yoon, "An empirical demonstration of classical comparative cost theory: A correction to Balassa (1963)," Applied Financial Economics, vol. 21, no. 23, pp. 1765-1767, August 2011.

[21] TurkStat. Business Statistics, Employment and wage Statistics. [Online]. Available: http://www.turkstat.gov.tr/VeriTabanlari.do?ust_id=9\&vt_id=52

[22] UNIDO, INDSTAT2 - 2012. Industrial Statistics Database. [Online]. Available: http://www.unido.org/index.php?id=1002105

[23] C. Hsiao, Analysis of Panel Data, 2nd edition, Econometric Society monograph, no. 34, Cambridge: Cambridge University Press, 2003.

[24] B. H. Baltagi, Econometric Analysis of Panel Data, Chichester, UK: Wiley, 2001.

[25] J. P. Elhorst, "Specification and estimation panel data models," International Regional Science Review, vol. 26, no. 3, pp. 244-268, July 2003.

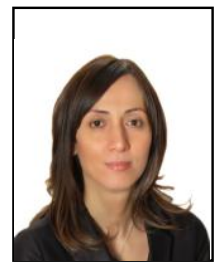

Sevcan Güneş was born in Denizli/Turkey in 01.11.1974. The B.S. degree was earned in the field of International Relations in the Middle East Technical University Ankara/Turkey in 1996. The Ms. and PhD degrees were earned in the field of economics in the Pamukkale University Denizli/Turkey in 2004 and Adnan Menderes University in Aydın/Turkey in 2008 The author's major field of study is the international economics, trade and development.

She has been working as an assistant prof. dr. at the Faculty of Economics and Administrative Sciences in Pamukkale University Denizli /Turkey since 2010. She worked as a research assistant in the Pamukkale University between 2001 and 2010. Author's some previous publications are Ş. Görmüş and S. Güneş, "Consumer Confidence,Stock Prices and Exchange Rates: The Case of Turkey," Applied Econometrics and International Development, vol.10,no:2,pp.103-114,2010, Ş. Görmüş and B. Güloğlu and S. Güneş, "Determinant of Stock Market Correlation: An Extended Gravity Model Approach," International Journal of Contemporary Economics and Administrative Sciences, Vol.1,No:4,pp.298-312,2011, S. Güneş and H.S. Karaalp, "Exports And Economic Growth: A Sectoral Analysis For Turkey," International Journal of Economics and Finance Studies, vol. 3, no 2,pp.255-265,2012. Current and previous research interests are international economics, trade and development.

Assist. Prof. Dr. Güneş is working as an analyst in the Pamukkale University Scientific Research Project No. 2012ARS08. She has been working for the organization of International Summer Seminars in Economics for 10 years.

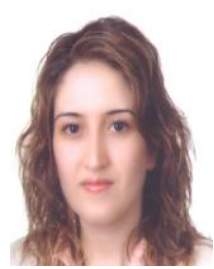

Hacer Simay Karaalp was born in Denizli/Turkey in 24.09.1979. The B.S. degree was earned in the field of agricultural economics in the Aegean University İzmir/Turkey in 2002. The Ms. and PhD. degrees were earned in the field of economics in the Pamukkale University Denizli/Turkey in 2004 and Adnan Menderes University in Aydın/Turkey in 2008. She was earned the second Ms. degree in the department of European Integration in the Middle East Technical University Ankara/Turkey in 2010. The author's major field of study is the international economics, trade and development.

She has been working as an assistant prof. dr. at the Faculty of Economics 
and Administrative Sciences in Pamukkale University Denizli /Turkey since 2010. She worked as a research assistant in the Pamukkale University between 2003 and 2010. Author's some previous publications are H.S. Karaalp and N.D. Yılmaz, "Assessment of trends in comparative advantage and competitiveness of Turkish textile and clothing industries in the enlarged EU market," Fibres \& Textiles in Eastern Europe, vol. 20, no.3, pp. 8-11, May/June 2012, H.S. Karaalp, "Effects of the customs union on comparative advantage of Turkish manufacturing industry," International Journal of Contemporary Economics and Administrative Sciences, vol.2, no.2, pp. 117-129, April 2012, H.S. Karaalp, "Competitiveness of Turkey in Eurasia: A comparison with CIS countries," China-USA Business Review, vol.10, no.9, pp. 727-744, September 2011. Current and previous research interests are international economics, trade and development.

Assist. Prof. Dr. Karaalp is the member of Academic Member of ATINER (Athens Institute for Education and Research), Athens, Greece and Society for the Study of Emerging Markets Inc. (SSEM) Chandler, USA. She is working as an analyst in the Pamukkale University Scientific Research Project No. 2011BSP016. She worked for the organization of $10^{\text {th }}$ Congress of Labor Economics and Industrial Economics in Pamukkale University in 2008 .

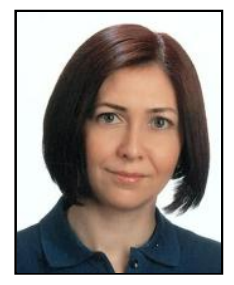

Filiz Yeșilyurt was born in Denizli/Turkey in 27.04.1976. The B.S. degree was earned in the field of Economics in the Hacettepe University Ankara/Turkey in 1999. The Ms. and PhD. degrees were earned in the field of economics in the Pamukkale University Denizli/Turkey in 2004 and Ege University in Izmir/Turkey in 2011. The author's major field of study is macro economics. She has been working as an assistant prof. at the Faculty of Economics and Administrative Sciences in Pamukkale University Denizli /Turkey since 2012. She worked as a research assistant in the Pamukkale University between 2002 and 2006 and 2006-2011 in the Ege University Izmir/Turkey. Author's some previous publications are "Sectoral Externalities in Turkey-The Spatial Analysis", (with M. E. Yeşilyurt), Yapi Kredi Economic Review, June 2008, "Efficiency Analysis of Turkish Preparation and Spinning of Textile Fibres; Weaving of Textiles Industry: The Cases of Firm-Based and Cumulative Data", (with M. E. Yeşilyurt), Topics in Middle Eastern and North African Economies-2008 Proceedings of the Middle East Economic Association, Volume 10, (2008), http://www.luc.edu/ orgs/meea/volume10/meea10.html. 